' Bell WR, Simon TL. Current status of pulmonary thromboembolic disease: pathophysiology, diagnosis, prevention, and treatment. $A m$ Heart $\mathcal{F} 1982 ; 103: 239-62$.

2 Ruckley CV, Thurston C. Pulmonary embolism in surgical patients: 1959-1979. Br Med f 1982;284:1100-3.

${ }^{3}$ Handley AJ. Low dose heparin after myocardial infarction. Lancet 1972; ii :623-4

- Warlow C, Terry G, Kenmure ACF, Beattie AG, Ogston D, Douglas AS. A double blind trial of low doses of subcutaneous heparin in the prevention of deep vein thrombosis after myocardial infarction. Lancet 1973; ii:934-6.

${ }^{5}$ McCarthy ST, Robertson D, Turner JJ, Haekey CJ, Macey DJ. Low-dose heparin as a prophylaxis against deep-vein thrombosis after acute stroke. Lancet 1977; ii:800-1.

${ }^{6}$ Hume M, Sevitt S, Thomas DP. Venous thrombosis and pulmonary embolism. Cambridge, Mass: Harvard University Press, 1970.

' Sasahara AA, Cannilla JE, Morse RL, Sidd JJ, Tremblay GM. Clinical and physiologic studies in pulmonary thromboembolism. $\mathrm{Am} \mathcal{F} \mathrm{Cardiol}$ 1967;20:10-20.

8 Bell WR, Simon TL, De Mets DL. The clinical features of submassive and massive pulmonary emboli. Am f Med 1977;62:355-60.

9 Belt TH. Thrombosis and pulmonary embolism. Am $\mathcal{F}$ Pathol 1934;10: 129-44.

10 Deykin D. Current concepts: the use of heparin. $N$ Engl f Med $1969 ; 280$ : 937-8.

11 Urokinase Pulmonary Embolism Study Group. Urokinase-streptokinase embolism trial. Phase 2 results. A cooperative study. F $A M A 1974 ; 229$ : 1606-13.

12. Smith RAG, Dupe RJ, English PD, Green J. Fibrinolysis with acylenzymes: a new approach to thrombolytic therapy. Nature $1981 ; 290$ : 505-8.

13 Greenfield LJ, Bruce TA, Nichols NB. Transvenous pulmonary embolectomy by catheter device. Ann Surg 1971;174:881-6.

14 Bentley PG, Kakkar VV, Scully MF, et al. An objective study of alternative methods of heparin administration. Thromb Res 1980;18:177-87.

${ }^{15}$ Miles RM, Chappell F, Renner O. A partially occluding vena caval clip for prevention of pulmonary embolism. Am Surg 1964;30:40-7.

\section{Hepatic granulomas}

Granulomas are focal accumulations of modified macrophages. They are thought to form when macrophages ingest poorly soluble antigens. These can be viral, bacterial, fungal, parasitic, or unrelated to infection or infestation, so that when granulomas are found in the liver many different causes have to be considered. ${ }^{1-6}$ Sarcoidosis and tuberculosis are high on the list in many series.

When liver biopsies are done in the course of investigation of systemic symptoms such as fever or loss of weight granulomas may be the principal or only histological abnormality. Clinician and pathologist must then set up series of further investigations until the cause is found. Alternatively, the pathologist may find one or more granulomas in a biopsy specimen showing changes of underlying liver disease. The granulomas may then help to establish the nature of this disease, as in primary biliary cirrhosis, in which granulomas are common in the early stages. ${ }^{7}$ In other instances the granulomas, while not contributing to the diagnosis, are readily explained; for example, granulomas form in fatty livers when fat-laden liver cells rupture. ${ }^{2}$ Sometimes granulomas seen in liver disease cannot be explained, and then it is prudent to try to exclude important causes such as tuberculosis, sarcoidosis, and brucellosis. Prolonged, exhaustive investigation is not, however, usually indicated.

To the pathologist hepatic granulomas fall into three groups. In the first the cause is seen under the microscope. Examples include granulomas forming around ova of Schistosoma mansoni and tuberculous lesions containing detectable tubercle bacilli. Unfortunately, few granulomas are so easily explained in Western countries, and even in proved tuberculosis bacilli are often not found histologically. ${ }^{146}$ In the second group the cause is not seen, but histological features of the granulomas themselves or of the associated liver disease strongly suggest the diagnosis. Examples are extensive caseous necrosis in tuberculosis and granulomas near damaged bile ducts in a biopsy specimen showing other features of primary biliary cirrhosis. A recently recognised member of this group of granulomas with helpful diagnostic features is the lesion of $Q$ fever: in some patients with this disease liver biopsy shows a distinctive pattern of epithelioid cells, segmented leucocytes, and fibrin surrounding fat vacuoles. ${ }^{8}{ }^{9}$ Histological characteristics are occasionally misleading, as in the rare instances of granulomas in sarcoidosis undergoing extensive necrosis. When histological features suggest but do not prove the diagnosis serological or microbiological confirmation is desirable.

In the third and last, unfortunately large, group the cause of the granulomas cannot be established with any degree of certainty, though there may be histological clues which help narrow the field and suggest a rational sequence of further investigation. An important cause of unexplained granulomas is drug hypersensitivity. McMaster and Hennigar ${ }^{5}$ attributed 28 of 95 examples of hepatic granulomas to therapeutic drugs, several of them in common use such as sulphonamides and methyldopa. Most patients had fever and hepatomegaly, and some had peripheral eosinophilia. Histologically the lesions were both portal and intralobular, eosinophils were common, and in some biopsy specimens granulomas were located near damaged small bile ducts.

When all likely causes of granulomas have been excluded with reasonable certainty clinically and histologically a group of puzzling patients remains. In Klatskin's large series of 565 patients with hepatic granulomas, ${ }^{4}$ no diagnosis could be established in 37. Nearly half of these had a prolonged feverish illness. Simon and Wolff ${ }^{10}$ have described an idiopathic granulomatous hepatitis characterised by prolonged or recurrent fever, often with loss of weight, myalgia, arthralgia, or abdominal pain. Most patients failed to respond to a trial of antituberculous drugs but subsequently improved with corticosteroids. Though different and as yet undefined causes may contribute to this kind of illness, it is perhaps among the few for which the poorly defined term granulomatous hepatitis is appropriate. Possibly some such patients may have the polymyalgia rheumatica and giant-cell arteritis syndrome without clinical evidence of temporal arteritis. ${ }^{11}$

Granulomas in a liver biopsy specimen may have prognostic as well as diagnostic implications. In a series of 100 patients with primary biliary cirrhosis ${ }^{7}$ granulomas were found less often in patients who subsequently died than in the survivors. Granulomas should therefore be taken into account in assessing the results of therapeutic trials in this disease. The relation between granuloma formation and clinical course needs confirmation and explanation, but it is in keeping with the known favourable prognostic implication of granulomas in other diseases such as Hodgkin's lymphoma and Crohn's disease.

\section{Peter J SCHEUER}

Professor of Clinical Histopathology,

Royal Free Hospital and School of Medicine, London NW3 2QG

${ }^{1}$ Guckian JC, Perry JE. Granulomatous hepatitis. An analysis of 63 cases and review of the literature. Ann Intern Med 1966;65:1081-100.

2 Iversen K, Christoffersen P, Poulsen $\mathbf{H}$. Epithelioid cell granulomas in liver biopsies. Scand $\mathcal{F}$ Gastroenterol 1970;suppl 7:61-7.

3 Neville E, Piyasena KHG, James DG. Granulomas of the liver. Postgrad Med f 1975;51:361-5.

4 Klatskin G. Hepatic granulomata: problems in interpretation. Ann NY Acad Sci 1976;278:427-32. 
${ }^{5}$ McMaster KR III, Hennigar GR. Drug-induced granulomatous hepatitis. Lab Invest $1981 ; 44: 61-73$.

${ }^{6}$ Cunningham D, Mills PR, Quigley EMM, et al. Hepatic granulomas experience over a 10-year period in the West of Scotland. $Q \mathcal{F ~} \mathrm{Med}$ $1982 ; 51$ (NS): $162-70$

${ }^{7}$ Lee RG, Epstein O, Jauregui H, Sherlock S, Scheuer PJ. Granulomas in primary biliary cirrhosis: a prognostic feature. Gastroenterology 1981 81 :983-6.

${ }^{8}$ Torres-Salinas M, Bruguera M, Cabrera J, Rodés J. Hepatitis por fiebre Q Gastroenterologia y Hepatologia 1978;1:230-2.

9 Pellegrin M, Delsol G, Auvergnat JC, et al. Granulomatous hepatitis in $\mathrm{Q}$ fever. Hum Pathol 1980;11:51-7.

${ }^{10}$ Simon HB, Wolff SM. Granulomatous hepatitis and prolonged fever of unknown origin: a study of 13 patients. Medicine (Baltimore) 1973;52 $1-21$.

11 Litwack KD, Bohan A, Silverman L. Granulomatous liver disease and gian cell arteritis. Case report and literature review. $\mathcal{F}$ Rheumatol 1977;4: 307-12.

\section{Blood donors with a history of jaundice}

Up till 1975 people with a history of jaundice were not acceptable as blood donors. The recommendation that this policy should be changed was made by an advisory group on testing for the presence of hepatitis B surface antigen ( $\mathrm{HBsAg}$; the "Australia" antigen) and its antibody." The group's recommendation was that potential donors should no longer be excluded provided that their blood did not contain detectable HBsAg and that they "had not suffered from hepatitis or jaundice during the previous 12 months."

In 1979 the group was reconvened to consider any changes in policy that might be desirable in the light of advances in knowledge, and its report appeared in 1981.2 Techniques for detecting HBsAg and its associated viral antigens and antibodies have improved rapidly, enzyme-linked immunoassay and radioimmunoassay taking the place of counterimmunoelectrophoresis and reverse passive haemagglutination. As a result, progressively fewer $\mathrm{HBsAg}$-positive donations have been found, most positive donors being rejected early. Regional transfusion centres in Britain now find between one in 500 and one in 1000 new donors to be $\mathrm{HBsAg}$ positive with an overall incidence of about one in 4000 in the donor population as a whole. Yet despite the increased rate of detection not all carriers can be identified, and $\mathrm{HBsAg}$-positive hepatitis (hepatitis B) still remains a hazard of blood transfusion.

The sensitivity of the method of testing is especially important for the use of some plasma products, rather than whole blood or packed cells. The products manufactured for treating the haemophilias, factor VIII and IX concentrates, are prepared from up to 5000 plasma donations, and the risk of contamination of these large pools is high. As a result the group has recommended that only the most sensitive techniques should be employed for all plasma donations sent for fractionation. The major difficulty in attempts to eliminate post-transfusion hepatitis, however, remains the absence of markers for the non-A, non-B viruses. So, though increased sensitivity of donor screening (together with the prospects ${ }^{3}$ for immunisation of at-risk groups) will virtually, but not completely, remove the threat of HBsAg-positive disease, the diagnosis of non-A, non-B hepatitis remains non-specific, and its true incidence remains unknown. Experience with haemophiliacs suggests that the non- $A$, non-B infection is often subicteric, presenting as a short incubation influenza-like illness, and diagnosed correctly only by maintaining a high level of suspicion and finding disordered liver function values. Because of this the extent and severity of post-transfusion hepatitis due to non- $A$, non-B viral infection have yet to be determined, though it is thought to account for $90 \%$ of all such cases in the United States. ${ }^{4}$ The diagnosis is important, because non-A, non-B infection may progress to chronic liver disease.

In Australia the only measures used to prevent posttransfusion hepatitis are the exclusion of donors jaundiced in the past two years and those whose donations are $\mathrm{HBsAg}$ positive on radioimmunoassay, and Cossart et $a l^{5}$ have recently reported the development of hepatitis in 18 of 842 patients undergoing cardiac surgery. Three infections were caused by hepatitis $\mathrm{B}$, one by cytomegalovirus, and 14 by probable non- $A$, non- $B$ viruses. The authors found a correlation between the non- $A$, non- $B$ infections and the presence of antibodies against hepatitis $B$ core antigen ( $\mathrm{HBcAg}$ ) and $\mathrm{HBsAg}$ in the donor blood but concluded that only about half the non-A, non-B infections might be avoided if routine surveillance for these markers was introduced. Aach and $\mathrm{Kahn}^{4}$ have suggested that screening of liver function, specifically by measuring alanine transaminase activity, would help eliminate some non-A, non-B infective donors.

Probably, then, the incidence of non- $A$, non- $B$ infection might be reduced by routine testing for antibodies against $\mathrm{HBcAg}$ and HBsAg and measuring alanine transaminase activity, but on present evidence about half the infective donations would still pass scrutiny. From the donor viewpoint the additional tests would be both expensive and time consuming. In Britain the risk implied in accepting donors with a history of jaundice is minor. But what of the recipient? From his viewpoint the present risk of developing disordered liver function after transfusion of volunteer $\mathrm{HBsAg}$-negative blood is about $10 \%,{ }^{6}$ and the risks rise with the number of donations he receives. Most of the experts at a recent international forum ${ }^{8}$ thought that this risk was unacceptable. Their conclusion was that donors with a history of jaundice (some $0.5 \%$ of the donor population ${ }^{6}$ ) should continue to be excluded.

British policy differs from this view, but the advisory group has recommended that doctors should be encouraged to report all cases of post-transfusion jaundice. Where these might be due to non-A, non-B hepatitis, the facts should be reported to the appropriate advisers in blood transfusion at the DHSS or Scottish Home and Health Department. ${ }^{2}$

Peter M Jones

Consultant Paediatrician,

Newcastle Haemophilia Centre,

Royal Victoria Infirmary,

Newcastle upon Tyne NE1 4LP

1 Advisory Group on Testing for the Presence of Hepatitis B Surface Antigen and its Antibody. Second report. London: DHSS, 1975.

2 Advisory Group on Testing for the Presence of Hepatitis B Surface Antigen and its Antibody. Third report. London: DHSS, 1981.

3 Zuckerman AJ. Priorities for immunisation against hepatitis B. Br Med $\mathfrak{F}$ 1982;284:686-8.

4 Aach RD, Kahn RA. Post-transfusion hepatitis: current perspectives. Ann Intern Med 1980;92:539-46.

5 Cossart YE, Kirsch S, Ismay SL. Post-transfusion hepatitis in Australia. Report of the Australian Red Cross Study. Lancet 1982;i:208-13.

${ }^{6}$ Alter HJ. Should donors with a history of jaundice still be rejected? Vox Sang $1981 ; 41: 112-3$.

7 Seef LB. Post-transfusion hepatitis. In: Seligsohn U, Horoszowski H, Rimon A, eds. Haemophilia. Tunbridge Wells : Castle House Publications, 1980:131-9.

${ }^{8}$ Anonymous. Should donors with a history of jaundice still be rejected ? Vox Sang 1981;41:110-27. 